\title{
2,4-ジブロモフェノキシ基を固定した固相抽出剤を用いる 玄麦中クロピラリドの定量
}

\author{
三輪 俊夫 ${ }^{\circledR 1}$, 鈴木 志穂 $^{1}$, 斎藤 勲 $^{1}$, 井上 嘉則 ${ }^{2}$, 山 本 敦 $^{1}$
}

\begin{abstract}
有機ハロゲン化合物に対する選択性の向上を目的とし, 高い分散力を発現する新規なポリマー系固相抽出 剤の開発を行った．グリシジル基を有する親水性ポリマー系基材に 2,4-ジブロモフェノキシ基を固定した固 相抽出郕（DBP 吸着剂）を調製し，分子内に塩素原子を有する除草剂クロピラリドに対する吸着特性の評価 を行った．DBP 吸着剤は，液液抽出に用いられている種々の有機溶媒中からクロピラリドを明確に吸着する ことが可能であった．この特性を生かし，玄麦中のクロピラリド分析の前処理への適用性を検討した．含水 アセトン溶液による玄麦試料の抽出液をDBP 吸着剤充填カートリッジに通液した後, 有機溶媒で洗浄するこ とにより，簡便にクロピラリドを精製することができ，高速液体クロマトグラフィー/紫外吸収検出にて容 易に定量可能であった．品種と産地が異なる 3 種の小麦と 1 種の大麦試料中に添加したクロピラリドの回収 率は, 88〜95\% $(n=3)$ と良好であった.
\end{abstract}

\section{1 緒言}

クロピラリド (3,6-dichloropyridine-2-carboxylic acid) は 広葉雑草に対して植物ホルモン作用を有する除草剤の一種 である，我が国での農薬登録はないが，海外では穀類，菜 種，トウモロコシなどに使用されているため, 我が国でも 暫定基準值が設定されている. 平成 20 年度の輸入米麦検 査ではアメリカ, カナダ, オーストラリアの三カ国の輸入 小麦検体のうち $17 \%$ から $0.01 \sim 0.04 \mathrm{ppm}$ のクロピラリ ドが検出されている ${ }^{1)}$.クロピラリドは非常に安定な化合 物であるため土壤などに残留しやすく，また哺乳類による 代謝も受けにくい2.．クロピラリドが残留している牛算堆 肥を利用した農家のトマトや菊などが生育障害を受けた例 も報告されている゙.

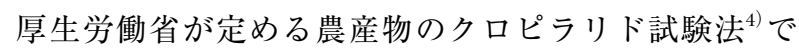
は, 溶媒抽出の後, ケイソウ土や $\mathrm{C} 18$ シリカゲルなどを用 いた多段階のカラム精製を経て液体クロマトグラフィー質量分析法（LC-MS）により測定することが規定されてい る. 精製工程の簡便化を目的として，QuEChERS 法兮によ る簡易精製の後, 液体クロマトグラフィー/タンデム質量 分析法（LC-MS/MS）で定量するという分析法が提案され ているが, 玄米中のクロピラリド分析においては高回収率

\footnotetext{
${ }^{\circledR}$ E-mail : gr12805-5449@sti.chubu.ac.jp

${ }^{1}$ 中部大学応用生物学部食品栄養科学科 : 487-8501 愛知県春日 井市松本町 1200

${ }^{2}$ 日本フイルコン株式会社総合研究開発部新規事業開発部 : 2068577 東京都稲城市大丸 2220
}

が得られていない ${ }^{6}$. LC-MS/MS による農薬の一斉分析法 では, 検量線の直線性 ${ }^{7)}$ や確認イオンの選定 ${ }^{8}$ 等幾つかの問 題点が指摘されている. MS のような高選択的検出器を用 いて被検種を定量する場合, 従来の試料前处理では夾雑成 分の除去が不十分であり，それに由来する妨害が分析值の 信頼性・安定性を欠く要因となってしまうため, より高度 な精製法の開発が必要となる.

そこで本研究では, 八ロゲン原子のもつ分散力に着目 し，有機ハロゲン化合物に対し高い選択性を発現する新規 の前処理用吸着剤の開発を試み, 簡便な固相抽出法による 濃縮・精製を行うことで, クロピラリドを高速液体クロマ トグラフィー法 (HPLC-UV) など沉用性の高い分析機器で 定量可能とすることを目指した. Kimata らは，臭素化ベン ジル基導入固定相において溶質との間に強い分散相互作用 が発現されることを報告している ${ }^{910)}$. 著者らは，臭素化 フェノキシ基を導入した固相抽出剤を新規に合成し，クロ ピラリドに対する保持特性を評価した，その結果，本固相 抽出剤はアセトンやアセトニトリルなど試料の溶媒抽出な ぞに多用される溶媒中でのクロピラリドに対して特異的捕 捉能を示し, 玄麦試料抽出液からの精製・濃縮が効率よく 行えることを見いだしたので報告する.

$$
2 \text { 実験 }
$$

\section{$2 \cdot 1$ 試 薬}

クロピラリドは Fluka 製（純度：99.3％）を用いた。メ タノールはメルク製（HPLC 用）を用いた。これ以外の試 薬は，和光純薬工業製の試薬特級または HPLC 用を用い 

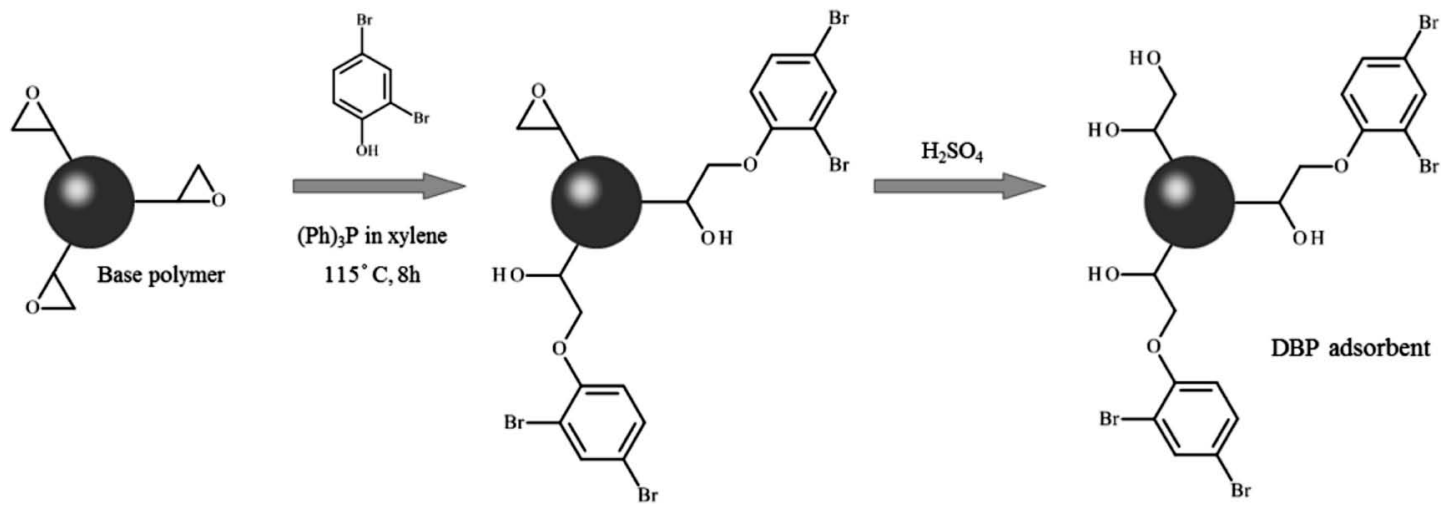

Fig. 1 Synthesis steps used for preparing clopyralid selective adsorbent DBP

た.クロピラリドの測定用原液は, クロピラリド $10 \mathrm{mg}$ エタノール（HPLC 用） $10 \mathrm{~mL}$ に溶解して調製し, 測定溶 液は，原液を適宜希釈して使用した，純水は，東レ製超純 水製造装置 LV408 で製造されたものを用いた。

\section{$2 \cdot 2$ 2,4-ジブロモフェノキシ基固定固相抽出剤（DBP 吸着剂）の調製}

2,4-ジブロモフェノキシ基を導入する基材樹脂は, 既 報 ${ }^{11)}$ に準じグリシジルメタクリレートとエチレンジメタク リレートとの共重合により合成し, 洗浄乾燥後, JIS 標準篩 を用いて 45〜90 $\mu \mathrm{m}$ に分級した. 基材樹脂中のエポキシ 基に対し 5 倍等量の 2,4- ジブロモフェノールを溶解させた キシレン溶液中に得られた基材樹脂を分散させ, トリフェ ニルホスフィンを触媒として $115{ }^{\circ} \mathrm{C}$ で 8 時間反応させた. 反応後の樹脂をアセトンで十分に洗浄し，その後に硫酸酸 性下にて樹脂に存在する未反応のエポキシ基を開環させジ オール基とした。 この樹脂をメタノールで十分に洗浄し, それを乾燥させ DBP 吸着剂を得た。 DBP 吸着剂の合成ス キームを Fig. 1 に示す. DBP 吸着剂 $100 \mathrm{mg}$ を, VARIAN 製空カートリッジ（容量 $1 \mathrm{~mL}$ ) に乾式充填した。作製し た DBP 吸着剤充填カートリッジは, 使用前にメタノール $10 \mathrm{~mL}$, 試料負荷に用いる溶媒 $10 \mathrm{~mL}$ を順次通液してコン ディショニングした.

\section{$2 \cdot 3$ HPLC 装置}

HPLC 装置は，島津製作所製 LC-10AD（VP）ポンプ，同 DGU-10A 脱気装置, 同 CTO-10A（VP）カラム恒温槽及び 同 SPD-6 検出器で構成した. 測定条件は以下の通り設定し た.カラム：GLサイエンス製InertSustain C18 (250 mm × $4.6 \mathrm{~mm}$ i.d., 粒子径 $5 \mu \mathrm{m}$ ), 移動相 : $50 \mathrm{mM}$ リン酸水溶 液一メタノール $\left(6+4\right.$ 容量), 流量 : $1.0 \mathrm{~mL} \mathrm{~min}^{-1}$, カラ 么温度 : $50{ }^{\circ} \mathrm{C}$, 検出波長 : $280 \mathrm{~nm}$, 注入量 : $5 \mu \mathrm{L}$.

\section{2・4 DBP 吸着剤におけるクロピラリドの吸脱着条件の}

\section{検討}

DBP 吸着剂におけるクロピラリドの吸脱着条件を設定 するため, クロピラリドの構造類似化合物を用いて DBP吸 着剂のハロゲン認識能を評価した。評価のための溶質に は, 安息香酸, ピリジンカルボン酸などのクロピラリドと 共通の官能基を有する 11 種の化合物を用いた。 これらの 溶質を各 $10 \mathrm{ppm}$ になるようにメタノール，エタノール， 2-プロパノール，アセトン及びアセトニトリルに溶解さ せ, その $10 \mathrm{~mL}$ を DBP 吸着剤充填カートリッジに通液し た.その後, メ夕ノール $-2 \%$ ジエチルアミン水溶液 $(7+3$ 容量 $) 10 \mathrm{~mL}$ で溶出させ, 溶出液中の各溶質を HPLC-UVにて測定し回収率を算出した.

\section{$2 \cdot 5$ 試験試料と調製}

試験試料には岩手県産大麦玄麦, 岩手県産小麦玄麦, そ して 2 種類の石川県産小麦玄麦の 4 種類の玄麦を用いた. 前処理操作のプロトコールを Fig. 2 に示す. ミルを用いて 均一化した玄麦試料 $50 \mathrm{~g}$ を正確に量り, ビーカーに移し た. 玄米や玄麦などの穀物試料は, 同量程度の水を加え 15 〜 30 分間ほど浸漬させた後にアセトンなどの溶解力の高 い有機溶媒を加えて抽出することで, 極性農薬に対し良好 な回収率を得ることが可能である ${ }^{12)}$. そこで, 本研究でも, 水 $50 \mathrm{~mL}$ を加え 30 分間静置した後にアセトン $150 \mathrm{~mL}$ を 加え, スパーテルで擋拌しながら 30 分間超音波を照射し 抽出を行った. ビーカー内容物すべてをプラスチック製遠 心沈殿管に移し, $4000 \mathrm{rpm}$ で 10 分間遠心分離を行い, 上 澄みを $200 \mathrm{~mL}$ のメスフラスコに移した。 さらに，沈殿物 にアセトン適量を加え，同様に擋拌下で超音波を照射し， 遠心分離により得た上澄みを先の上澄みと合わせた，得ら れた上澄みを，アセトンで $200 \mathrm{~mL}$ に定容したものを玄麦 抽出液とした。玄麦抽出液 $5 \mathrm{~mL}$ をDBP 吸着剤 $200 \mathrm{mg}$ 充 填カートリッジに通過させた後, アセトン $5 \mathrm{~mL}$ とメ ノール $10 \mathrm{~mL}$ を順次通液して DBP 吸着剤の洗浄を行った. 


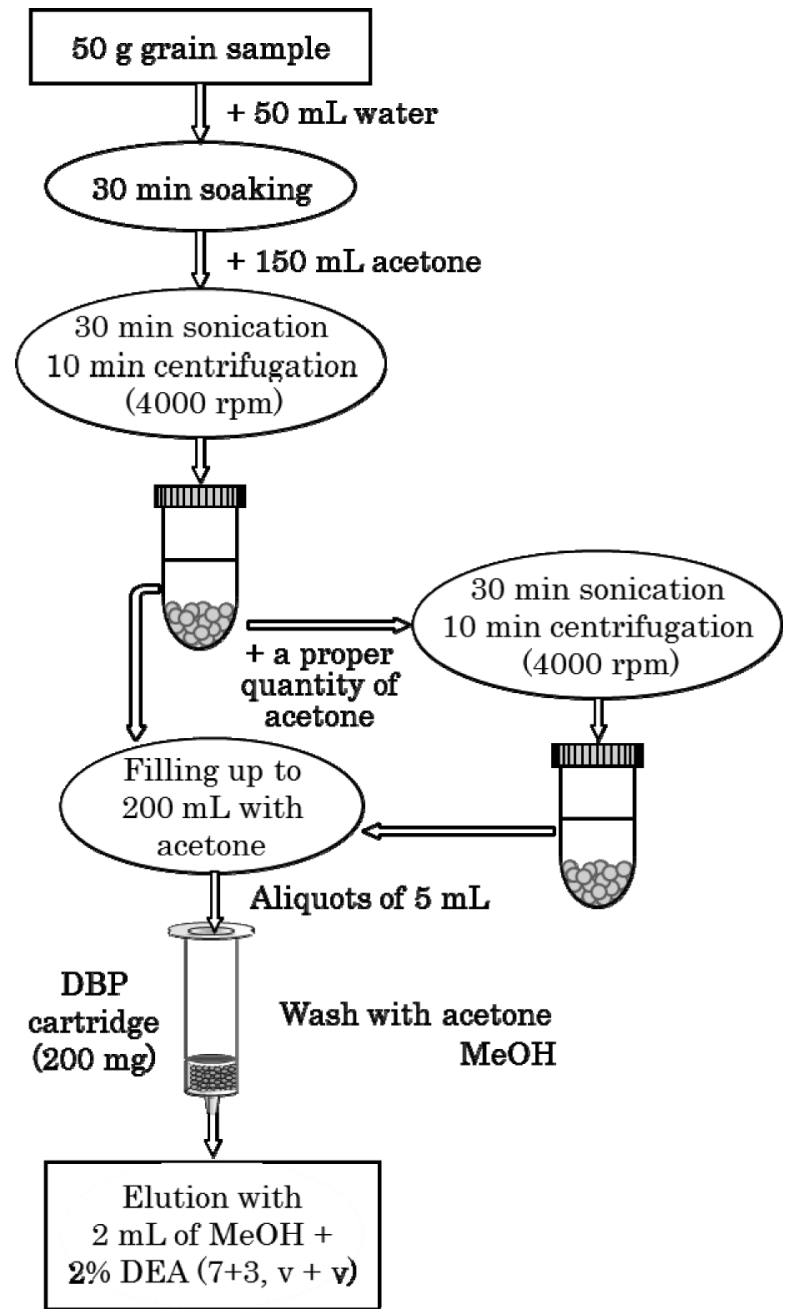

Fig. 2 Schematic diagram of the pretreatment procedure by the proposed method
DBP 吸着剤に捕捉されたクロピラリドの溶出は, メタノー ル-2％ ジエチルアミン水溶液 $(7+3$ 容量 $) 2 \mathrm{~mL}$ で行っ た.この溶出液を HPLC-UVに供した.

\section{3 結果と考察}

\section{$3 \cdot 1$ DBP 吸着剤におけるクロピラリドの吸脱特性}

DBP 吸着剂を用いた各種有機溶媒における各化合物の 回収率を Table 1 に示す. 置換基を持たないベンゼンやピ リジン，また塩素のみを置換基に有するジクロロベンゼン やジクロロピリジンに対する回収率は非常に低く, DBP 吸 着剤はこれらに対して高い親和性を示さなかった。一方, カルボキシル基を有する化合物に対しては親和性を示し, エタノールを用いた時の回収率は, 安息香酸<2-ピリジン カルボン酸 $<2,5$ - ジクロロ安息香酸<クロピラリドの順 であった．また，2-プロパノール及びアセトニトリル中に おいて，2-ピリジンカルボン酸，2,5-ジクロロ安息香酸及 びクロピラリドは完全に吸着された。これらのことから, カルボキシル基と塩素を併せ持つ化合物の場合には飛躍的 に親和性が増強されること, ベンゼン環よりピリジン環を 有する化合物のほうに高い親和性を示すことが推定され た. それらすべてを満たすクロピラリドが最も高い回収率 を示した。

溶媒間で溶質に対する親和性に大きな差異が見られた が，これは溶媒が有するプロトン受容体の溶解パラメータ $\delta_{\mathrm{a}}{ }^{13)}$ に基づくものと考えられる. Table 1 に示した $\delta_{\mathrm{a}}$ 值は ヒドロキシ基やカルボキシル基に対する親和力の指標であ り, 評価に使用した有機溶媒群においてはアセトニトリル とアセトンが最小で, メタノールが最大である.この $\delta_{\mathrm{a}}$ 值 の順は Table 1 における溶質の回収率の順と一致しており, 溶質分子のカルボキシル基及び固定相のヒドロキシ基に対 する溶媒の親和性の差が選択性や吸着の強さに大きく寄与 しているものと推測された.

DBP 吸着剂に吸着されたクロピラリドは, メタノールー

Table 1 Recovery experiments for clopyralid and its analogue on a DBP cartridge

\begin{tabular}{|c|c|c|c|c|c|}
\hline \multirow{2}{*}{ Solute } & \multicolumn{5}{|c|}{ Solvents } \\
\hline & Methanol (7.5) & Ethanol (5) & 2-Propanol (4) & Acetonitrile (2.5) & Acetone (2.5) \\
\hline Benzene & $\mathrm{nr}$ & $\mathrm{nr}$ & $\mathrm{nr}$ & $\mathrm{nr}$ & $\mathrm{nr}$ \\
\hline Chlorobenzene & $\mathrm{nr}$ & $\mathrm{nr}$ & $\mathrm{nr}$ & $\mathrm{nr}$ & $\mathrm{nr}$ \\
\hline 1,4-Dichlorobenzene & $\mathrm{nr}$ & $\mathrm{nr}$ & $\mathrm{nr}$ & $\mathrm{nr}$ & $\mathrm{nr}$ \\
\hline Pentachlorobenzene & $\mathrm{nr}$ & $\mathrm{nr}$ & $\mathrm{nr}$ & $\mathrm{nr}$ & $\mathrm{nr}$ \\
\hline Benzoic acid & $\mathrm{nr}$ & 51.0 & 85.1 & 98.0 & 85.9 \\
\hline 2,5-dichlorobenzoic acid & 49.6 & 98.7 & 98.5 & 99.4 & $>100$ \\
\hline Pyridine & $\mathrm{nr}$ & $\mathrm{nr}$ & $\mathrm{nr}$ & $\mathrm{nr}$ & $\mathrm{nr}$ \\
\hline 2-chloropyridine & $\mathrm{nr}$ & $\mathrm{nr}$ & $\mathrm{nr}$ & $\mathrm{nr}$ & $\mathrm{nr}$ \\
\hline 2,5-dichloropyridine & $\mathrm{nr}$ & $\mathrm{nr}$ & $\mathrm{nr}$ & $\mathrm{nr}$ & $\mathrm{nr}$ \\
\hline 2-pyridinecarboxylic acid & 24.4 & 63.1 & 97.6 & 99.1 & 49.7 \\
\hline Clopyralid & 98.9 & 99.8 & 93.0 & $>100$ & 99.3 \\
\hline
\end{tabular}

nr, not retained. number in the parenthesis corresponds to $\delta_{\mathrm{a}}$ value 


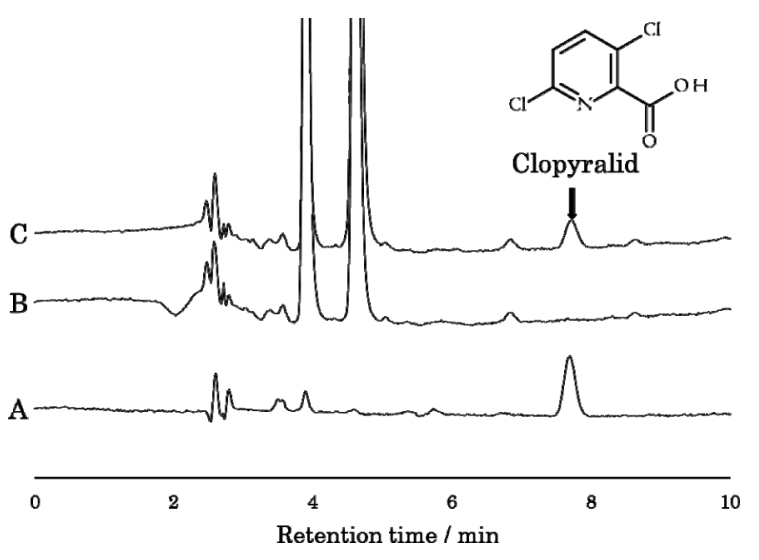

Fig. 3 Typical chromatograms of (A) clopyralid standard solution $\left(1 \mu \mathrm{g} \mathrm{g}{ }^{-1}\right)$, and wheat sample (B) without and $(\mathrm{C})$ with clopyralid addition $\left(0.625 \mu \mathrm{g} \mathrm{g}^{-1}\right)$

水混合溶媒ではほとんど溶出されなかった，そこで，ヒド ロキシ基やカルボキシル基に対する親和力の切断を目的と して, メタノールー水混合溶媒に酸あるいはアミンを添加 して溶出性を調べた，その結果，ジエチルアミンを添加す ることにより速やかに溶出され，メタノール $-2 \%$ ジエチ ルアミン水溶液 $(7+3$ 容量 $)$ が最適な組成であった. クロ ピラリドのカルボキシル基と DBP 官能基根元のヒドロキ シ基間とのクーロン力に対し, 酸はカルボキシル基と競合 し，またアミンはヒドロキシ基と競合するためにクロピラ リドの脱着に効果を発揮したものと推定された。

分散力は疎水性相互作用などの主体であり，その相互作 用は 2〜 $5 \mathrm{~J} \mathrm{~mol}^{-1}$ と非常に弱く ${ }^{1415)}$, 有機溶媒などにより 容易に相互作用が断ち切られてしまうほどの強さである. DBP 吸着片を用いた今回の結果においても，塩素基のみを 有する溶質は吸着されなかったことから，水素結合や極性 的な相互作用が同時に寄与したことで八ロゲン基による分 散力をより強固なものにしたものと考えられた。

\section{$3 \cdot 2$ DBP 吸着剤の実試料への適用}

DBP 吸着剤に扔けるハロゲン認識能は, 複雑な夾雑成分 を持つ試料中のハロゲン化芳香族カルボン酸の抽出・精製 に有効であると考えられる，そこで，玄麦中のクロピラリ ド分析の前処理への DBP 吸着剤の適用性を調べた。

クロピラリド標準溶液, 岩手県産大麦玄麦の抽出液及び それにクロピラリドを標準添加した抽出液のクロマトグラ 厶を Fig. 3 に示す. HPLC の移動相条件は移動相中のメ夕 ノール比率をクロピラリドが $7 〜 8$ 分に検出されるように した．標準溶液のクロマトグラム（Fig. 3A）から求めた検 出限界は, 絶対注入量で $0.5 \mathrm{ng}(s / n=3)$ であった。 ま た，ピーク面積值を基に作成した検量線は，0.5 50 ng の 範囲で良好な直線 $\left(r^{2}=1.000\right)$ を与えた。

DBP 吸着剂を利用し固相抽出を行った岩手産大麦玄麦
試料のクロマトグラムを Fig. 3B に示す．本試料中からは クロピラリドは検出されなかったため, これを空試験試料 とした添加回収実験を行った。この大麦玄麦抽出液に玄麦 試料あたり $1 \mathrm{ppm} に$ 相当するクロピラリドを添加し, 得ら れた最終溶液のクロマトグラムを Fig. 3C に示す. UV 検出 器を用いて測定を行う場合, 光吸収を有する夾雑成分によ る妨害を受けやすいため, 高い定量性を確保するためには 前処理における精製度の向上が必要となる。しかし，DBP 吸着剂を適用した本法ではその夾雑成分に由来するバック グラウンド及びピークは大幅に減少しており, クロピラリ ドのピークを十分に確認することが可能となった．さらに 品種の異なる他の国産玄麦 3 種類についても同様の実験を 3 回繰り返し行い, それぞれの試料の平均值を算出したと ころ $88 \sim 95 \%$ の回収率が得られた. 試料検体あたりのク ロピラリドの検出限界は $0.16 \mu \mathrm{g} \mathrm{g}^{-1}$ であり, 今回適用した 玄麦試料に対して十分に対応可能であった.

$$
4 \text { 結 言 }
$$

今回作製した DBP 吸着剤が有するジブロモフェノキシ 基は分散力に基づくハロゲン選択性を発現し, 分子内に塩 素を有するクロピラリドへの高い選択性と強い親和力を発 揮した，その結果, DBP 吸着剂は, 従来の逆相・順相と いった保持機構とは異なる保持特性を示し，抽出や精製で 用いられる沉用有機溶媒中に溶解したクロピラリドを強固 に吸着することが可能であった. DBP 吸着郕を玄麦試料へ 適用したところ，非常に簡便な前処理操作で夾雑成分を大 幅に除去することが可能となり，HPLC-UV 法によるクロ ピラリドの高感度測定に成功した，これらの結果から，他 の穀物や野菜, 堆肥などのクロピラリド分析においても, 分析に要する操作と時間を大幅に削減できる可能性が示唆 された．さらに，LC-MS/MSなどを用いることで微量のク ロピラリドに対してもバックグラウンドの低いクロマトグ ラム上で高感度・高選択的に検出を行うことも期待でき る. 有用な吸着剤であることが判明した。

\section{文献}

1) 農林水産省 : 玄麦の残留農薬などの調查結果「20 年度に政府が買い付けた輸入米麦の残留農薬等の分 析結果の取りまとめ」, (2008). < http://www.maff. go.jp/j/syouan/nouan/kome/k_beibaku/pdf/h20_ yunyu.pdf $>$, (accessed 2012-3-16).

2）八木寿治, 関根優子, 白井裕治: 肥料研究報告, 3 , 51 (2010).

3) R. Uegaki, M. Ebato, M. Sutoh, Y. Cai : Grassland Sci., 55, 135 (2009).

4) 厚生労働省通知, 食安発第 1003001 , 平成 18 年 10 月 3 日。

5) M. Anastassiades, S. J. Lehotay, D. Stajnbaher, F. J. Schenck: J. AOAC Int., 86, 412 (2003).

6) U. Koesukwiwat, K. Sanguankaew, N. 
Leepipatpiboon : Anal. Chim. Acta, 626, 10 (2008).

7) Y. Fillâtre, D. Rondeau, B. Bonnet, A. Daguin, A. Jadas-Hécart, P-Y. Communal : Anal. Chem., 83, 109 (2011).

8) A. Schaner, J. Konecny, L. Luckey, H. Hickes : J. AOAC Int., 90, 1402 (2007).

9) K. Kimata, T. Hirose, K. Moriuchi, K. Hosoya, T. Araki, N. Tanaka : Anal. Chem., 67, 2556 (1995).

10) M. Turowski, N. Yamakawa, J. Meller, K. Kimata, T. Ikegami, K. Hosoya, N. Tanaka, E. R. Thornton : J. Am. Chem. Soc., 125, 13836 (2003).

11) T. Tsukamoto, A. Yamamoto, W. Kamichatani, Y.
Inoue: Chromatographia, 70, 1525 (2009).

12) 坂真智子, 飯島和昭, 狛由紀子, 藤田眞弘, 小田中 芳次, 加藤保博 : 日本農薬学会誌, 31, 431 (2006).

13) 千原秀昭, 稲葉 章訳: “アトキンス物理化学要 論”, 第 3 版, p. 335 (2003), (東京化学同人) ; P. W. Atkins: "The Elements of Physical Chamistry Third Edition”, (2001), (Oxford University Press).

14) 中村 洋監修: “分析試料前処理ハンドブック”, p. 146 (2003), (丸善).

15) 中村 洋監修: “高速液体クロマトグラフィーハン ドブック”, p. 179 (2000), (丸善).

\title{
Determination of Clopyralid in Whole Grain Using Solid Phase Extractant Immobilizing with 2,4-Dibromophenoxy Group
}

\author{
Toshio Miwa $^{\circledR 1}$, Shiho Suzuki ${ }^{1}$, Isao SAIto ${ }^{1}$, Yoshinori InOuE ${ }^{2}$ and Atsushi Yamamoto ${ }^{1}$ \\ ${ }^{\circledR}$ E-mail : gr12805-5449@sti.chubu.ac.jp
}

${ }^{1}$ College of Bioscience and Biotechnology, Chubu University, 1200, Matsumoto-cho, Kasugai-shi, Aichi 4878501

${ }^{2}$ Products Planning \& Development Dep., Research \& Development Center, Nippon Filcon Co., LTD., 2220, Ohmaru, Inagi-shi, Tokyo 206-8577

(Received March 16, 2012 ; Accepted June 18, 2012)

A novel solid-phase extractant that will demonstrate a dispersion force was synthesized to improve the extraction efficiency for halogenated solutes, including clopyralid (3,6-dichloro-2pyridinecarboxylic acid), which is widely used as a herbicide. The 2,4-dibrominated phenoxy group was immobilized on the surface of a hydrophilic methacrylate resin. The solid-phase extraction properties for the halogenated solutes were evaluated by solid-phase extraction using a cartridge packed with the synthesized extractant. Clopyralid and its analogues, i.e. benzoic acid, 2,5-dichlorobenzoic acid, pyridine carboxylic acid and so on, were used as probes. This dispersion-force extractant could selectively entrap the halogenated aromatic carboxylic acids including clopyralid in every organic solvent used for the extraction of pesticide residues. The extractant was applied to the analysis of clopyralid in whole-grain samples. The extracts of the milled whole grain by water-acetone solution were passed through the extractant. Cropyralid trapped on the extractant was eluted by a methanol-water solution containing diethylamine after washing the extractant with an organic solvent ; then, the effluent was measured by the HPLC-UV method. The detection limit on the optimized method was 0.16 $\mu \mathrm{g} \mathrm{g}^{-1}$ for clopyralid. The recoveries of clopyralid in four kinds of whole grain were good with $88-95 \%$ in triplicate.

Keywords : dispersion force ; solid phase extractant ; clopyralid ; halogenated compounds ; whole grain. 